attributable mortality. JAMA 1994;271:1598-1601.

14. Fagon JY, Novara A, Stephan F, Girou E, Safar M. Mortality attributable to nosocomial infections in the ICU. Infect Control Hosp Epidemiol 1994;15:428-434.

15. Fagon JY, Chastre J, Vuagnat A, Trouillet JL, Novara A, Gilbert C. Nosocomial pneumonia and mortality among patients in intensive care units. JAMA 1996;275:866-869.

16. Townsend TR, Wenzel RP. Nosocomial bloodstream infections in newborn intensive care unit: a case-matched control study of morbidity, mortality, and risk. Am J Epidemiol 1981;114:73-80.

17. Craven DE, Kunches LM, Lichtenberg DA, et al. Nosocomial infection and fatality in medical and surgical intensive care unit patients. Arch Intern Med 1988;148:1161-1168.

18. Bueno-Cavanillas A, Gelgado-Rodriguez M, Lopex-Luque A, Schaffino-Cano S, Galvaz-Vargas R. Influence of nosocomial infection on mortality in an intensive care unit. Crit Care Med 1994;22:55-60.

19. Driks MR, Craven DE, Celli BR, et al. Nosocomial pneumonia in intubated patients given sucralfate as compared with antacids or histamine type 2 blockers. $N$ Engl J Med 1987;317:1376-1382.

20. Kollef MH. Ventilator-associated pneumonia. A multivariate analysis. JAMA 1993;270:1965-1970.
21. Craig CP, Connelly S. Effect of intensive care unit nosocomial pneumonia on duration of stay and mortality. Am J Infect Control 1984;12:233-238.

22. Leu HS, Kaiser DL, Mori M, Woolson RF, Wenzel RP. Hospitalacquired pneumonia: attributable mortality and morbidity. Am J Epidemiol 1989;129:1258-1267.

23. Torres A, Aznar R, Gatell JM, et al. Incidence, risk and prognostic factors of nosocomial pneumonia in mechanically ventilated patients. Am Rev Respir Dis 1989;139:877-884.

24. Fagon JY, Chastre J, Hence AJ, Montravers P, Novara A, Gilbert C. Nosocomial pneumonia in ventilated patients: a cohort study evaluating attributable mortality and hospital stay. Am J Med 1993;94:281-288.

25. Fagon JY, Chastre J, Domart Y, et al. Incidence, risk and prognostic factors of nosocomial pneumonia in mechanically ventilated patients. Am Rev Respir Dis 1989;139:877-884.

26. Diaz-Molina C, Garcia MM, Bueno CA, Lopez LA, Delgado RM, Galvez VR. The estimation of the cost of nosocomial infection in an intensive care unit. Medicina Clinica 1993;100:329-332.

27. French GL, Cheng AF. Measurement of the costs of hospital infection by prevalence surveys. J Hosp Infect 1991;18:65-72.

\title{
CDC’s Global Surveillance System Budget Approved
}

\section{Gina Pugliese, RN, MS; Martin S. Favero, PhD Medical News Editors}

The Clinton administration requested a $\$ 26$ million budget increase in 1997 over the 1996 funding level to expand the CDC's National Center for Infectious Disease (NCID) Emerging Infectious Disease program to control the worldwide spread of infectious diseases. In June, the House Appropriations Committee completed markup of their FY97 HHS Appropriations Bill that provides $\$ 82$ million for CDC's NCID-\$20 million above the 1996 funding level and approximately \$5 million short of the President's request. This would represent a $32 \%$ increase in NCID's budget, compared to the modest $2.9 \%$ increase in the overall FY97 funding level appropriated for the CDC.
The committee report cites the 1992 Institute of Medicine Report on Emerging Infections: Microbial Threats to Health in the United States and the four pillars (surveillance, applied research, prevention and control, and developing infrastructure) of the CDC's responding strategic plan. The committee directs the CDC to address the infrastructure development component of the plan as a priority, citing the deterioration of local, state, and federal laboratories as handicapping effective disease surveillance efforts.

The additional funding also would support what Vice-President Al Gore called "a global surveillance system.” A key component of the plan is a worldwide system of computer links with other countries lacking such technology. It also would allow the CDC to expand the number of regional infectious disease centers in the United States. Other aspects of this initiative are expansion of the training programs within the $\mathrm{Na}$ tional Institute of Health, allowing foreign researchers to use Defense Department Laboratories abroad to conduct special tests and studies, and expanding private sector input by scientists and healthcare companies already working with the government to prevent the spread of disease.

The Senate Appropriation Committee was scheduled to review the bill in mid-July.

FROM: Associated Press. Infectious disease control plan gets highlevel backing. Washington Post; June 13, 1996:A 27; and NCID's FY 97 Budget. Pro MED Digest Tuesday, July 2, 1996;(96) 141. 